\title{
CAREERS
}

CoLUMN Expertise is overrated sometimes naivety is best. p.281
FUNDING Website helps researchers to attract private support p.281
NATUREJOBS For the latest career

listings and advice www.naturejobs.com

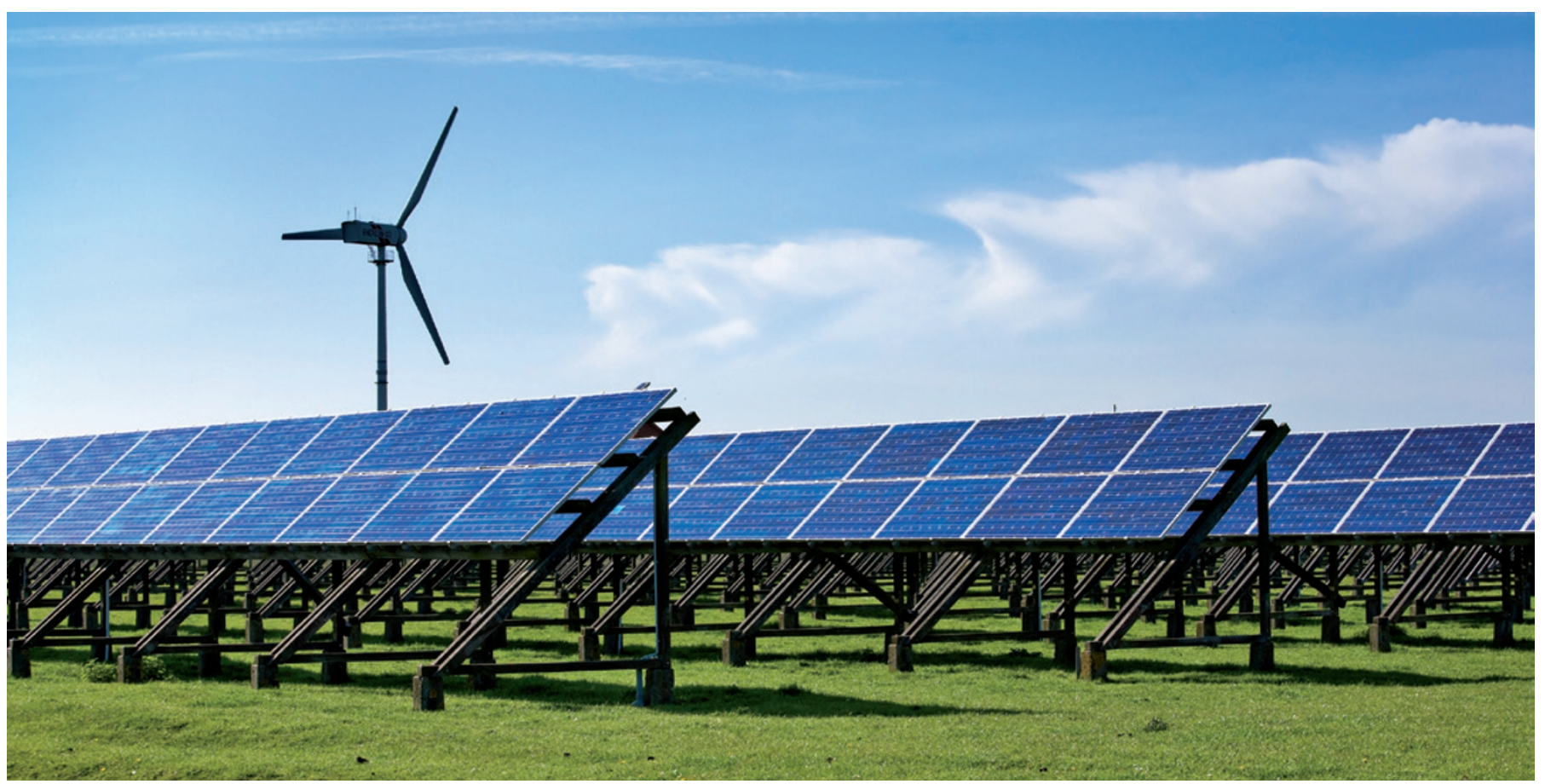

The German government and private sector are pouring money into energy research and infrastructure, such as this solar-energy plant in North Frisia.

\section{Renewables revolution}

\section{Europe's largest economy is boosting research on alternative energy sources and generating job opportunities.}

\section{BY QUIRIN SCHIERMEIER AND KATRIN KOHNERT}

$\mathrm{M}$ arcus Bär is a prime target for headhunters. An electrical engineer, he leads an independent young-investigator group at the Helmholtz Centre Berlin for Materials and Energy (HZB), working on next-generation, high-performance thin-film solar cells. But his research experience has also attracted the interest of private-sector solar-energy companies throughout Germany, which are aggressively recruiting skilled scientists and engineers. Bär has received some tempting job offers, he says - but has opted to stay in his tenure-track academic position.

Solar research at the HZB is one of many alternative-energy initiatives to get under way in Germany in recent years. Energy research has long been a priority for the German government, but the meltdown in March at the Fukushima Daiichi nuclear plant in Japan gave it extra urgency. Before the disaster, nuclear energy had supplied some $23 \%$ of Germany's electricity demand. But immediately after the meltdown, the German government withdrew the licences of seven older nuclear reactors (see Nature 472, 505; 2011), and later decided it would shut down the nine remaining reactors by the end of 2022. This has added impetus to plans for investment in energy research over the next several years.

In August, just weeks after announcing the nuclear phase-out, the government approved a $€ 3$.5-billion (US\$4.7-billion) energy-research programme for 2011-14 - a 75\% increase over the 2006-09 funding period. Of that, some $€ 2.5$ billion is earmarked for research on renewable energy and energy efficiency.

This means plenty of new jobs, for researchers at private companies as well as those at institutes that rely on government funding. Analysts with the German Institute of Economic Research in Berlin estimate that over the next decade, several hundred thousand skilled jobs could be generated in the renewable-energy sector, many for scientists and engineers. Companies and institutes will be recruiting from home and abroad; indeed, bringing in more foreign talent is a government policy.

\section{VARIETY AND SCOPE}

The job market spans a multitude of topics in basic and applied research, says Bernd Emonts, deputy head of the Institute of Energy and Climate Research at the Jülich Research Centre (FZJ), who oversees more than 100 people 
> working on fuel cells. Future work will focus not only on how to gain energy from renewable sources, but also on how to store and distribute electricity. The government's energy investment will allow the FZJ to expand nascent research on the potential of batteries and hydrogen for efficient energy storage. As energy research becomes a national priority, the centre will seek scientists and engineers from disciplines including material sciences, physical chemistry, chemical and material engineering and mathematics.

"The market for new technologies, and the demand for young researchers who can develop it, will boom for many years to come," says Joachim Fuchs, programme manager for renewable energies at the Karlsruhe Insti-

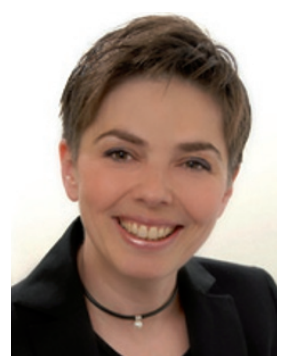

"For me, the change to industry has been the right career move at the right time." Aleksandra Saša Bukvić-Schäfer tute of Technology (KIT), which will benefit from both the public funding and industry investment. In October, the institute opened the Battery and Electrochemistry Laboratory (BELLA) in partnership with chemical giant BASF, which is based in Ludwigshafen. Over the next 5 years, the KIT and BASF each plan to invest $€ 6$ million in energy-storage and electric-car research at the centre, which is about to advertise for 4-6 postdoctoral scientists.

Ideal candidates, says Jürgen Janek, a physical chemist and co-director of BELLA, would have a background in electrochemistry and skills in solid-state chemistry, nanotechnology or material sciences. But those with a general background in, for example, physics or inorganic chemistry could also find opportunities: employers can often train such candidates relatively quickly on the job, says Janek.

\section{INDUSTRIAL OPPORTUNITIES}

Renewable-energy technology in Germany was once the domain of small and mediumsized companies. But in September, one of the country's largest and most research-intensive companies - Siemens, headquartered in Munich - announced plans to withdraw from nuclear power and focus on the booming renewables sector. Michael Weinhold, chief technology officer of Siemens Energy in Erlangen, says that the company will focus on everything from developing small technical components to installing large facilities such as offshore wind farms and solar thermal power stations, and ultra-high-voltage technologies for optimized grids and improved energy transmission. Siemens Energy is constantly looking for well-trained young scientists and

engineers, ideally with expertise in renewable energies, but also with more general bachelor's or master's degrees in electrical, chemical or mechanical engineering. Weinhold declined to provide exact hiring numbers.

Janek says that with so many groups and companies currently recruiting, "the market for highly skilled specialists is pretty much swept clean". Rapid growth in the field can mean a high turnover of personnel. The Fraunhofer Institute for Wind Energy and Systems Technology in Kassel and Bremerhaven, for example, hired around 50 specialists this year, but it also lost 15 scientists to industry. Some academics have recognized the opportunities. Aleksandra Saša Bukvić-Schäfer last year moved from the Fraunhofer Institute to SMA Solar Technology in Niestetal, a leading provider of photovoltaic technologies. "For me, the change to industry has been the right career move at the right time," she says. "I'm still involved in research on electrochemical energy storage, but my work here is more focused, less project-oriented - and better paid." Indeed, in response to increasing demand, salaries for industry-employed engineers have risen by more than $4 \%$ this year. Starting salaries range from an average of $€ 42,000$ for engineers with bachelor degrees to $€ 52,000$ for PhD holders.

\section{GAP IN THE JOB MARKET}

German technology companies, however, are facing a severe shortage of skilled engineers. The Association for German Engineers (VDI) in Düsseldorf reported that September saw a record number of private-sector vacancies - almost 100,000, many of them in renewable energy and electro-mobility. Bosch Solar Energy in Erfurt - a division of Bosch, one of the largest technology companies in Germany - is injecting $€ 530$ million into a centre for photovoltaics in Arnstadt. The centre will have up to 1,000 skilled technical and engineering jobs by 2012. "Electrical and mechanical engineers

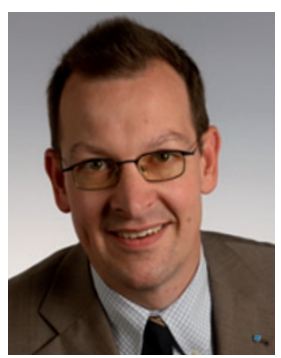

"Electrical and mechanical engineers are particularly sought after." Lars Funk are particularly sought after," says Lars Funk, head of the VDI's profession and society division. "That doesn't mean that companies are cutting back on requirements with regards to applicants' skills. But employment opportunities are considerably improving."

Next year, to make foreign hires more attractive to companies, the government is to lower the minimum annual salary that companies must pay specialists from outside the European Union (EU) before they can get a permanent work permit in Germany from $€ 66,000$ to $€ 40,000$.

Until now, foreign recruitment has been less successful than the government hoped. Companies are often unsure about the value of foreign degrees and qualifications, especially with regard to applicants from outside the EU. And employers must deal with work permits and pay relatively high salaries for skilled non-EU researchers. Academic jobs, which usually offer fixed-term appointments, are generally a better prospect for foreign scientists. Residence permits are easier to get — scientists can apply for a researcher's visa - and there is no minimum salary required to obtain a work permit.

\section{DEGREE OF DIFFERENCE}

To help to meet the demand, German research and applied-science universities offer more than 100 postgraduate renewable-energy programmes - covering aspects from basic science to energy economics and environmental management. Some programmes focus on specific technologies; for example, the Technical University of Berlin runs a master's programme in engineering for solar technology. Others, such as the University of Oldenburg's master of science in renewable energy, provide basic knowledge across different sectors. Most programmes are taught in English and encourage foreign students to apply. After the course, job prospects are good: most graduates of the Oldenburg programme go on to $\mathrm{PhD}$ research or take up positions in industry; others move on to careers in climate diplomacy or financial consulting, for instance, says Konrad Blum, an energy researcher at Oldenburg.

Prospective students should look into the curricula of the different programmes to see whether they provide qualifications relevant to the student's desired career path, says Theo Buehler, a career expert at the Wissenschaftsladen Bonn, a private 'science shop' that provides advice on the job market and qualification requirements in energy and environment sectors. To capitalize on the looming personnel shortage, the science shop recommends that students acquire solid core knowledge in a particular field, such as chemistry, before going on to specialize in renewable energy through a postgraduate programme. Language skills and flexibility are prerequisites, and business skills are an increasingly sought-after extra, says Buehler.

Bär knows that his own students and postdocs at the HZB are not immune to the lure of industry. "The best ones are the first to leave," he says. "So you've got to make sure that there is always enough fresh talent around. But looking at the many Asian, Middle Eastern and Latin American faces in my lectures, I'm not at all concerned that the well might run dry." -

Quirin Schiermeier is Nature's Germany correspondent. Katrin Kohnert is a former Nature intern, based in Munich. 